\title{
Short communication: Effects of milk fat depression induced by a dietary supplement containing trans-10, cis-12 conjugated linoleic acid on properties of semi-hard goat cheese
}

\author{
S. X. Chen, ${ }^{\star} \dagger$ M. Rovai,† A. L. Lock,‡ D. E. Bauman,§ T. A. Gipson, † F. Z. Ren, ${ }^{* 1}$ and S. S. Zeng ${ }^{1}$ \\ ${ }^{*}$ College of Food Science \& Nutritional Engineering, China Agricultural University, Beijing 100083, China \\ †E (Kika) de la Garza American Institute for Goat Research, Langston University, Langston, OK 73050 \\ ‡Department of Animal Science, University of Vermont, Burlington 05405 \\ §Department of Animal Science, Cornell University, Ithaca, NY 14853
}

\section{ABSTRACT}

Dietary supplements of conjugated linoleic acid (CLA) containing trans-10, cis-12 CLA reduce milk fat synthesis in lactating goats. This study investigated effects of milk fat depression induced by dietary CLA supplements on the properties of semi-hard goat cheese. Thirty Alpine does were randomly assigned to 1 of 3 groups and fed diets with lipid-encapsulated CLA that provided trans-10, cis-12 CLA at 0 (control), 3 (CLA1 ), and $6 \mathrm{~g} / \mathrm{d}$ (CLA-2). The experiment was a $3 \times 3$ Latin square design. Periods were 2 wk in length, each separated by 2 -wk periods without CLA supplements. Bulk milk was collected on d 3 and 13 of each of 3 periods for cheese manufacture. The largest decrease $(23.2 \%)$ in milk fat content, induced by the high dosage (6 g/d per doe) of trans-10, cis-12 CLA supplementation at d 13 of treatment, resulted in decreases of cheese yield and moisture of 10.2 and $10.0 \%$, respectively. Although CLA supplementation increased the hardness, springiness, and chewiness, and decreased the cohesiveness and adhesiveness of cheeses, no obvious defects were detected and no significant differences were found in sensory scores among cheeses. In conclusion, milk fat depression induced by a dietary CLA supplement containing trans-10, cis-12 CLA resulted in changes of fat-to-protein ratio in cheese milk and consequently affected properties of semi-hard goat cheese.

Key words: conjugated linoleic acid, milk fat depression, semi-hard goat cheese

Conjugated linoleic acid (CLA) is a generic term for octadecadienoic acid isomers with conjugated double bonds. Two CLA isomers, cis-9, trans-11 and trans-10, cis-12, have been shown to possess many health ben-

\footnotetext{
Received January 6, 2009.

Accepted February 13, 2009.

${ }^{1}$ Corresponding authors: renfazheng@263.net and shoushanz@ yahoo.com
}

efits in animal and human models (Mark and Pariza, 1998). Dairy products are a major source of CLA in human diets and the major CLA isomer in milk fat is cis-9, trans-11 CLA (Bauman and Lock, 2006). Studies in dairy cows have demonstrated that milk composition can be modified by changes in feeding system or directly through dietary CLA supplementation (Bauman and Lock, 2006). However, when diets were supplemented with mixed isomers of CLA, a reduction in the content and yield of milk fat was observed (Chouinard et al., 1999; Perfield et al., 2002). In subsequent research the trans-10, cis-12 isomer of CLA was documented as a potent inhibitor of milk fat synthesis in dairy cows and sheep (Bauman et al., 2008) as well as goats (Lock et al., 2008).

For semi-hard goat cheeses, TS, fat, and protein contents of bulk milk are regarded as the dominant factors that affect cheese yield and properties (Fekadu et al., 2005; Olson et al., 2007). Hence, changes in cheese milk composition resulting from CLA supplementation may affect cheese yield, composition, and properties. The objective of this study was to investigate the effects of CLA-induced milk fat depression on yield, composition, sensory score, and texture profile of semi-hard goat cheeses.

Experimental procedures involving goats and CLA supplements have been described in a companion report (Lock et al., 2008). Briefly, 30 Alpine does were selected and randomly divided into 3 groups in a $3 \times 3$ Latin square design with 3 dietary supplementation treatments that supplied trans-10, cis-12 CLA at 0 (control), $3 \mathrm{~g} / \mathrm{d}$ (CLA-1) and $6 \mathrm{~g} / \mathrm{d}$ (CLA-2). Experimental periods were 2 wk in length, each separated by a 2 -wk washout period. The CLA supplement was a lipid-encapsulated formulation containing $10 \%$ trans-10, cis-12 CLA and 10\% cis-9, trans-11 CLA (BASF Corporation, Queich, Germany).

Milk for cheese manufacture was collected twice $(0500$ and $1600 \mathrm{~h})$ on d 3 and 13 of treatment, and duplicate samples were taken for analyses of fat, protein, 
Table 1. Changes of cheese milk compositions and SCC induced by dietary supplementation of trans-10, cis-12 conjugated linoleic acid (CLA) ${ }^{1}$

\begin{tabular}{|c|c|c|c|c|c|c|c|c|}
\hline \multirow[b]{2}{*}{ Milk composition } & \multicolumn{4}{|c|}{ Treatment period (d 3) } & \multicolumn{4}{|c|}{ Treatment period (d 13) } \\
\hline & Control & CLA-1 & CLA-2 & SEM & Control & CLA-1 & CLA-2 & SEM \\
\hline Fat, $\%$ & $3.21^{\mathrm{a}}$ & $3.22^{\mathrm{a}}$ & $3.03^{\mathrm{b}}$ & 0.05 & $3.40^{\mathrm{a}}$ & $3.11^{\mathrm{b}}$ & $2.61^{\mathrm{c}}$ & 0.12 \\
\hline Protein, \% & 2.53 & 2.53 & 2.54 & 0.09 & 2.57 & 2.58 & 2.58 & 0.06 \\
\hline Casein, \% & 2.05 & 2.04 & 2.03 & 0.03 & 2.07 & 2.08 & 2.09 & 0.05 \\
\hline Casein-to-protein ratio & 0.81 & 0.81 & 0.81 & 0.01 & 0.80 & 0.81 & 0.81 & 0.01 \\
\hline Protein-to-fat ratio & $0.79^{\mathrm{b}}$ & $0.79^{\mathrm{b}}$ & $0.83^{\mathrm{a}}$ & 0.01 & $0.76^{\mathrm{b}}$ & $0.81^{\mathrm{b}}$ & $0.94^{\mathrm{a}}$ & 0.07 \\
\hline Casein-to-fat ratio & 0.64 & 0.63 & 0.67 & 0.02 & $0.61^{\mathrm{b}}$ & $0.67^{\mathrm{b}}$ & $0.80^{\mathrm{a}}$ & 0.06 \\
\hline Lactose, $\%$ & 4.21 & 4.23 & 4.24 & 0.04 & 4.19 & 4.20 & 4.16 & 0.05 \\
\hline TS, $\%$ & 10.81 & 10.84 & 10.66 & 0.08 & $11.04^{\mathrm{a}}$ & $10.91^{\mathrm{a}}$ & $10.44^{\mathrm{c}}$ & 0.07 \\
\hline $\mathrm{SCC}(\log / \mathrm{mL})$ & 6.02 & 5.93 & 5.97 & 0.16 & 5.94 & 6.01 & 6.03 & 0.10 \\
\hline
\end{tabular}

lactose, TS, and SCC at the certified DHIA Laboratory for Goats (Langston University, OK). Additional milk samples were also taken and stored at $-20^{\circ} \mathrm{C}$ for later analysis of casein (AOAC, 2000).

Semi-hard cheese was prepared at the certified pilot creamery (Langston University, OK) following the procedure of Kosikowski and Mistry (1999) with slight modifications. Cheese blocks (about $3 \mathrm{~kg}$ each) were cut into 2 sub-blocks, one being subsequently sampled and analyzed for chemical composition, texture profile, and sensory score, and the other being vacuum-packed and aged at $8^{\circ} \mathrm{C}$ for $60 \mathrm{~d}$. Cheese yield was calculated as percentage of milk used (wt/wt). For statistical analysis, moisture-adjusted cheese yields $\left(\mathbf{Y}_{\mathbf{M A}}\right)$ were arithmetically calculated from actual yields $\left(\mathbf{Y}_{\mathbf{A}}\right)$ based on the formula $\mathrm{Y}_{\mathrm{MA}}=\mathrm{Y}_{\mathrm{A}} \times(100-$ moisture $) /(100-$ average moisture). Cheese yield in dry matter $\left(\mathbf{Y}_{\mathbf{D M}}\right)$ was calculated as $\mathrm{Y}_{\mathrm{DM}}=\mathrm{Y}_{\mathrm{A}} \times(100-$ moisture $) / 100$.

Cheeses were warmed to room temperature $(21 \pm$ $1^{\circ} \mathrm{C}$ ) for $1 \mathrm{~h}$ before sampling for texture profile analysis (TPA). Cylindrical samples were taken with a cork borer (no. 9, $15 \mathrm{~mm}$ in diameter) and cut to the same height. Five representative samples were taken from one sub-block, and TPA was conducted using an Instron texture analyzer (model 5500, Instron Corporation, Canton, MA). Texture variables (hardness, springiness, cohesiveness, chewiness, and adhesiveness) were calculated using TPA software (Instron Corp.). A panel of 3 trained judges evaluated cheese samples for sensory quality using a 15-point scale, with 10 points designated for flavor and 5 points for body and texture (Bodyfelt et al., 1988). Data for milk and cheese compositions including cheese texture profile (hardness, springiness, cohesiveness, adhesiveness, and chewiness) and sensory score were all analyzed using the GLM procedure of SAS for Windows (version 8.0; SAS Institute, 2002), with period and group considered as random effects and treatment a fixed effect. The $t$-test (least significant difference) was used to test the difference of means among treatments at a significant level of 0.05 .

Bulk milk used for cheese manufacture did not differ $(P>0.05)$ among treatments for protein, casein, and lactose contents, casein-to-protein ratio, or SCC (Table 1). However, milk fat content was affected by the dietary CLA supplement with effects being more pronounced by d 13 of treatment. At d 13 of treatment, fat contents of CLA-1 and CLA-2 cheese milk decreased 8.5 and $23.2 \%$, respectively, compared with that of control cheese milk. Because of the reduction in milk fat, the CLA treatments had increased protein-to-fat ratio, casein-to-fat ratio, and decreased TS (Table 1).

Inhibition of milk fat synthesis by trans-10, cis-12 CLA has been well documented in dairy cows, and the potential application of this in dairy production has been discussed (Griinari and Bauman, 2006). Similar reductions in milk fat synthesis have been observed for lactating sheep fed dietary supplements containing trans-10, cis-12 CLA (Lock et al., 2006; Sinclair et al., 2007). In the companion paper (Lock et al., 2008) it was reported that the dietary supplement containing trans-10, cis-12 CLA also reduced milk fat, but at comparable doses (metabolic BW basis), the magnitude of the decrease in milk fat synthesis was less than that observed for cows and sheep (Lock et al., 2008). Recently, Shingfield et al. (2009) made similar observations and concluded that the reduction in milk fatty acids was more marked for de novo synthesized fatty acids $(\leq 16$ carbons in length), thereby resulting in a shift in milk fatty acid composition to an increased proportion of long-chain unsaturated fatty acids (Lock et al., 2008). We analyzed the fatty acid composition of cheeses produced in the present study and found treatment differ- 
Table 2. Changes of yield and composition of fresh semi-hard goat cheese induced by dietary supplementation of trans-10, cis-12 conjugated linoleic acid (CLA) $)^{1}$

\begin{tabular}{|c|c|c|c|c|c|c|c|c|}
\hline \multirow[b]{2}{*}{ Item $^{2}$} & \multicolumn{4}{|c|}{ Treatment period (d 3) } & \multicolumn{4}{|c|}{ Treatment period (d 13) } \\
\hline & Control & CLA-1 & CLA-2 & SEM & Control & CLA-1 & CLA-2 & SEM \\
\hline $\mathrm{Y}_{\mathrm{A}}, \mathrm{g} / \mathrm{kg}$ & 99.60 & 98.73 & 97.03 & 1.99 & $100.59^{\mathrm{a}}$ & $94.62^{\mathrm{b}}$ & $90.34^{\mathrm{c}}$ & 1.02 \\
\hline Moisture, \% & 44.48 & 43.87 & 43.09 & 0.97 & $44.83^{\mathrm{a}}$ & $43.12^{\mathrm{a}}$ & $40.34^{\mathrm{b}}$ & 1.07 \\
\hline Fat in DM, \% & 49.07 & 49.42 & 48.13 & 1.36 & $49.74^{\mathrm{a}}$ & $48.62^{\mathrm{a}}$ & $42.41^{\mathrm{b}}$ & 1.22 \\
\hline Protein in DM, \% & 36.65 & 37.15 & 37.19 & 1.42 & $37.28^{\mathrm{b}}$ & $37.87^{\mathrm{b}}$ & $40.39^{\mathrm{a}}$ & 1.01 \\
\hline Fat, $\%$ & 27.24 & 27.74 & 27.39 & 1.02 & $27.44^{\mathrm{a}}$ & $27.26^{\mathrm{a}}$ & $25.30^{\mathrm{b}}$ & 0.94 \\
\hline Protein, $\%$ & 20.35 & 20.85 & 21.17 & 0.62 & $20.58^{\mathrm{b}}$ & $21.54^{\mathrm{b}}$ & $24.10^{\mathrm{a}}$ & 0.88 \\
\hline MNFS, $\%$ & $61.13^{\mathrm{a}}$ & $60.71^{\mathrm{a}}$ & $59.35^{\mathrm{b}}$ & 0.54 & $61.79^{\mathrm{a}}$ & $59.60^{\mathrm{b}}$ & $54.01^{\mathrm{c}}$ & 0.44 \\
\hline $\mathrm{Y}_{\mathrm{MA}}, \mathrm{g} / \mathrm{kg}$ & 98.39 & 98.61 & 98.26 & 1.61 & $98.22^{\mathrm{a}}$ & $95.26^{\mathrm{b}}$ & $95.39^{\mathrm{b}}$ & 1.04 \\
\hline $\mathrm{Y}_{\mathrm{DM}}, \mathrm{g} / \mathrm{kg}$ & 55.30 & 55.42 & 55.22 & 0.52 & $55.50^{\mathrm{a}}$ & $53.82^{\mathrm{b}}$ & $53.90^{\mathrm{b}}$ & 0.62 \\
\hline Fat recovery, $\%$ & $84.52^{\mathrm{b}}$ & $85.05^{\mathrm{b}}$ & $87.14^{\mathrm{a}}$ & 0.802 & $81.19^{c}$ & $84.14^{\mathrm{b}}$ & $87.24^{\mathrm{a}}$ & 1.029 \\
\hline Protein recovery, $\%$ & 77.06 & 77.89 & 78.09 & 1.96 & $77.53^{\mathrm{b}}$ & $76.05^{\mathrm{b}}$ & $81.23^{\mathrm{a}}$ & 1.168 \\
\hline $\mathrm{pH}$ & 6.15 & 6.02 & 5.97 & 0.273 & 6.05 & 5.95 & 6.08 & 0.165 \\
\hline
\end{tabular}

${ }^{a-c}$ Means $(\mathrm{n}=6)$ in the same row with different superscript letters within treatment period differed $(P<0.05)$ according to LSD.

${ }^{1}$ Goats were fed 1 of 3 dietary treatments that supplied trans-10, cis-12 CLA at 0,3, and $6 \mathrm{~g} / \mathrm{d}$ for control, CLA-1, and CLA-2 groups, respectively.

${ }^{2} \mathrm{Y}_{\mathrm{A}}=$ actual yield; MNFS $=$ moisture in nonfat substrate; $\mathrm{Y}_{\mathrm{MA}}=$ moisture-adjusted yield; $\mathrm{Y}_{\mathrm{DM}}=$ yield in DM.

ences similar to those for milk so that the CLA-induced increase in the proportion of long-chain unsaturated fatty acids was maintained in the cheeses (data not presented). Shingfield et al. (2009) concluded that CLA in the diet inhibited milk fat synthesis but was less sensitive to the antilipogenic effects of trans-10, cis-12 CLA in goats than in cows or sheep.

Effects of fat depression induced by dietary supplementation of CLA on the yield and composition of fresh semi-hard goat cheese are shown in Table 2. For the cheeses made from milk from d 3 of CLA supplementation, moisture contents were not significantly different $(P$ $>0.05$ ), but moisture in the nonfat substrate (MNFS) of CLA-2 cheese $(59.4 \%)$ was significantly lower $(P<$ $0.05)$ than that of CLA-1 and control cheeses (60.7 and $61.1 \%$, respectively). No significant differences $(P>$ 0.05 ) were observed in cheese fat, protein, fat in DM, $\mathrm{Y}_{\mathrm{A}}, \mathrm{Y}_{\mathrm{MA}}, \mathrm{Y}_{\mathrm{DM}}$, fat recovery, protein recovery, and $\mathrm{pH}$. After $13 \mathrm{~d}$ of CLA supplementation, changes in cheese milk composition resulted in variations of cheese yield and composition. Cheese yields of CLA-1 and CLA-2 decreased 5.9 and $10.2 \%$ compared with the control, and both $\mathrm{Y}_{\mathrm{MA}}$ and $\mathrm{Y}_{\mathrm{DM}}$ were reduced. Fat content (25.3\%) and fat in DM (42.4\%) of CLA-2 cheese were lower compared with those of CLA-1 and control cheeses, whereas protein content and protein in DM were higher. Supplementation with CLA resulted in positive effects on the contents of cheese protein and negative effects on the contents of cheese fat, MNFS, $\mathrm{Y}_{\mathrm{MA}}$, and $\mathrm{Y}_{\mathrm{DM}}$. Supplementation with CLA affected cheese $\mathrm{Y}_{\mathrm{A}}$ and moisture content to various degrees depending on supplementation dosage and duration (Table 2). The increase in casein-to-fat ratio can be attributed to the reduction of fat content without changes in casein content with CLA supplementation. Our cheese yield results differed from observations of Sinclair et al. (2007) with dairy sheep; they reported that cheese yield was not affected by dietary CLA supplements despite the decrease in milk fat; they attributed this to an improvement in the milk casein-to-fat ratio. In previous investigations involving the production of semi-hard goat cheese, TS was positively correlated with cheese yield (Zeng et al., 2007). Thus, in the present study the observed decrease in cheese yield was consistent with the CLA-induced reduction in TS.

Effects of fat depression induced by CLA supplementation on texture profile and sensory score of fresh and 60-d aged goat cheeses are shown in Table 3 . There were no effects on cheeses made from fresh goat milk obtained after d 3 of CLA supplementation $(P>0.05)$. However, after $60 \mathrm{~d}$ of aging, springiness of CLA-2 cheeses was greater than that of CLA-1 and control cheeses, and cohesiveness for CLA-2 and CLA-1 cheeses was lower than that of control. For cheeses made from bulk milk obtained on d 13 of CLA supplementation, significant differences $(P<0.05)$ in hardness and chewiness of fresh cheeses were found among treatments. Hardness and chewiness of CLA-1 and CLA-2 fresh cheeses were greater than those of control cheeses. After $60 \mathrm{~d}$ of aging, hardness of CLA-1 and CLA-2 cheeses was maintained at 21 to $22 \mathrm{~N}$, significantly greater than that of control $(\sim 17 \mathrm{~N})$. Springiness of CLA-2 cheeses was greater, whereas cohesiveness of control cheeses was higher than that of the cheeses from the CLA treatment groups. Chewiness differed significantly among control, CLA1 , and CLA-2 cheeses $(47.8,69.9$, and $95.6 \mathrm{~N} \times \mathrm{mm}$, 
Table 3. Texture profile (means, $\mathrm{n}=15$ ) and sensory score (means, $\mathrm{n}=9$ ) of fresh and 60-d-aged semi-hard goat cheese from 3 treatment groups ${ }^{1}$

\begin{tabular}{|c|c|c|c|c|c|c|c|c|}
\hline \multirow[b]{2}{*}{ Item } & \multicolumn{4}{|c|}{ Treatment period $(3 \mathrm{~d})$} & \multicolumn{4}{|c|}{ Treatment period $(13 \mathrm{~d})$} \\
\hline & Control & CLA-1 & CLA-2 & SEM & Control & CLA-1 & CLA-2 & SEM \\
\hline \multicolumn{9}{|l|}{ Fresh cheese $(1 \mathrm{~d})$} \\
\hline Hardness, $\mathrm{N}$ & 11.17 & 12.52 & 11.11 & 0.76 & $13.65^{\mathrm{b}}$ & $21.22^{\mathrm{a}}$ & $22.33^{\mathrm{a}}$ & 1.18 \\
\hline Springiness, mm & 8.08 & 7.93 & 8.14 & 0.17 & 7.74 & 7.67 & 7.97 & 0.16 \\
\hline Cohesiveness, ratio & 0.69 & 0.7 & 0.69 & 0.02 & 0.58 & 0.59 & 0.61 & 0.02 \\
\hline Chewiness, $\mathrm{N} \times \mathrm{mm}$ & 61.5 & 69.0 & 62.0 & 4.78 & $60.8^{\mathrm{b}}$ & $95.3^{\mathrm{a}}$ & $109.2^{\mathrm{a}}$ & 6.85 \\
\hline Adhesiveness, $\mathrm{J} \times 10^{-3}$ & -0.10 & -0.08 & -0.11 & 0.04 & -0.27 & -0.34 & -0.30 & 0.08 \\
\hline Score, texture & 3.67 & 3.75 & 3.59 & 0.14 & 3.65 & 3.55 & 3.58 & 0.07 \\
\hline Score, flavor & 8.05 & 8.17 & 8.08 & 0.12 & 8.08 & 8.08 & 7.95 & 0.16 \\
\hline \multicolumn{9}{|l|}{ Aged cheese $(60 \mathrm{~d})$} \\
\hline Hardness, N & 12.78 & 14.30 & 13.04 & 0.95 & $16.71^{\mathrm{b}}$ & $20.93^{\mathrm{a}}$ & $21.99^{\mathrm{a}}$ & 1.05 \\
\hline Springiness, mm & $6.78^{\mathrm{b}}$ & $6.85^{\mathrm{b}}$ & $8.02^{\mathrm{a}}$ & 0.46 & $5.90^{\mathrm{b}}$ & $6.01^{\mathrm{b}}$ & $8.03^{\mathrm{a}}$ & 0.51 \\
\hline Cohesiveness, ratio & $0.63^{\mathrm{a}}$ & $0.57^{\mathrm{b}}$ & $0.58^{\mathrm{b}}$ & 0.02 & $0.59^{\mathrm{a}}$ & $0.48^{\mathrm{b}}$ & $0.35^{\mathrm{c}}$ & 0.02 \\
\hline Chewiness, $\mathrm{N} \times \mathrm{mm}$ & 53.4 & 52.7 & 62.1 & 6.05 & $47.8^{\mathrm{c}}$ & $69.9^{\mathrm{b}}$ & $95.6^{\mathrm{a}}$ & 7.94 \\
\hline Adhesiveness, $\mathrm{J} \times 10^{-3}$ & -0.67 & -0.76 & -0.61 & 0.09 & $-1.11^{\mathrm{a}}$ & $-1.11^{\mathrm{a}}$ & $-0.75^{\mathrm{b}}$ & 0.12 \\
\hline Score, texture & 4.65 & 4.67 & 4.57 & 0.19 & 4.71 & 4.55 & 4.53 & 0.22 \\
\hline Score, flavor & 9.67 & 9.75 & 9.58 & 0.41 & 9.65 & 9.45 & 9.57 & 0.22 \\
\hline
\end{tabular}

${ }^{a-c}$ Means in the same row with different superscript letters differed $(P<0.05)$ according to LSD.

${ }^{1}$ Goats were fed 1 of 3 dietary treatments that supplied trans-10, cis-12 CLA at 0,3 , and $6 \mathrm{~g} / \mathrm{d}$ for control, CLA-1, and CLA-2 groups, respectively.

respectively). Adhesiveness of CLA-2 cheeses ( $-0.75 \mathrm{~J}$ $\times 10^{-3}$ ) was higher than that of CLA-1 and control $\left(-1.11\right.$ and $-1.11 \mathrm{~J} \times 10^{-3}$, respectively). It was also observed that chewiness and adhesiveness of all cheeses decreased as cheeses aged.

Cheese texture is recognized as one of the most important quality attributes that determine cheese identity and affect consumer perception (Rosenthal, 1999). Texture profile analysis is widely used for cheese texture examination and is especially useful for making comparisons (Tunick and Van Hekken, 2002). In our study, CLA supplementation resulted in the decline of milk fat content, and consequently affected the content of cheese fat. Therefore, the effect of CLA supplementation on cheese texture should be mainly ascribed to reduction of fat content. Bryant et al. (1995) reported that when fat was reduced in Cheddar cheese, the microstructure of the network was altered, and hardness and springiness increased whereas adhesiveness and cohesiveness decreased. Gwartney et al. (2002) investigated 5 commercial cheeses and concluded that the texture of cheese became harder and more waxy, chewy, and springy when fat was reduced. Similar changes were found in the present study: hardness, springiness, and chewiness increased whereas adhesiveness and cohesiveness decreased to various degrees when fat content was reduced by CLA supplementation. Although the largest decline in milk fat content reached $23.2 \%$ for CLA-2 compared with control milk, the fat content of CLA-2 cheese was only $7.8 \%$ lower than that of control cheese. The decline of fat in CLA-2 cheese could be attributed to CLA-2 milk being lower in fat and higher in casein- to-fat ratio than control milk and to the greater loss of milk fat in whey during cheese manufacture. The decline might also have been offset, to some degree, by decreases in cheese moisture and yield. Therefore, changes in cheese texture profile were not intensive, and no strong defects among cheeses were detected by sensory panel evaluations. During aging, hardness increased whereas springiness, cohesiveness, and chewiness decreased; a similar temporal pattern was reported by Chevanan et al. (2006) for Gouda and Cheddar cheeses produced from cow's milk. In the present study, there were no significant effects of CLA supplementation on sensory scores of the cheeses, although slight differences in hardness and springiness were detected by the judges.

In conclusion, the largest decrease $(23.2 \%)$ of fat content, induced by long-term (13 d) and high dosage (6 g/d of trans-10, cis-12 CLA) supplementation, resulted in decreases in cheese yield of $10.2 \%$ and cheese moisture of $10.0 \%$. Although the hardness, springiness, and chewiness of cheeses increased and cohesiveness and adhesiveness decreased when cheese milk fat was reduced by trans-10, cis-12 CLA supplementation, no strong defects were detected among cheeses of different CLA supplementations, and no significant differences were found in sensory scores of the cheeses.

\section{REFERENCES}

AOAC. 2000. Dairy products. Pages 51-53 in Official Methods of Analysis. Association of Official Analytical Chemists, Washington, DC.

Bauman, D. E., and A. L. Lock. 2006. Conjugated linoleic acid: Biosynthesis and nutritional significance. Pages 93-135 in 
Advanced Dairy Chemistry, Vol. 2: Lipids. P. E. Fox and P. L. H. McSweeney, ed. Springer, New York, NY.

Bauman, D. E., J. W. Perfield II, K. J. Harvatine, and L. H. Baumgard. 2008. Regulation of fat synthesis by CLA: Lactation and the ruminant model. J. Nutr. 138:403-409.

Bodyfelt, F. W., J. Tobias, and G. M. Trout. 1988. The Sensory Evaluation of Dairy Products. Van Nostrand Reinhold, New York, NY.

Bryant, A., Z. Ustunol, and J. Steffe. 1995. Texture of Cheddar cheese as influenced by fat reduction. J. Food Sci. 60:1216-1219.

Chevanan, N., K. Muthukumarappan, P. Upreti, and L. E. Metzger. 2006. Effect of calcium and phosphorus, residual lactose and saltto-moisture ratio on textural properties of Cheddar cheese during ripening. J. Texture Stud. 37:711-730.

Chouinard, P. Y., L. Corneau, A. Sæbø, and D. E. Bauman. 1999 Milk yield and composition during abomasal infusion of conjugated linoleic acids in dairy cows. J. Dairy Sci. 82:2737-2745.

Fekadu, B., K. Soryal, S. Zeng, D. Van Hekken, B. Bah, and M. Villaquiran. 2005. Changes in goat milk composition during lactation and their effect on yield and quality of hard and semihard cheeses. Small Rumin. Res. 59:55-63.

Griinari, J. M., and D. E. Bauman. 2006. Milk fat depression: Concepts, mechanisms and management. Pages 389-417 in Ruminant Physiology: Digestion, Metabolism and Impact of Nutrition on Gene Expression, Immunology and Stress. K. Sejrsen, T. Hvelplund, and M. O. Nielson, ed. Wageningen Academic Publishers, Wageningen, the Netherlands.

Gwartney, E. A., E. A. Foegeding, and D. K. Larick. 2002. The texture of commercial full-fat and reduced-fat cheese. J. Food Sci. $67: 812-816$.

Kosikowski, F. V., and V. V. Mistry. 1999. Cheese and Fermented Milk Foods. F. V. Kosikowski LLC, Great Falls, VA.

Lock, A. L., M. Rovai, T. A. Gipson, M. J. de Veth, and D. E. Bauman. 2008. A conjugated linoleic acid (CLA) supplement containing trans-10, cis-12 CLA reduces milk fat synthesis in lactating goats. J. Dairy Sci. 91:1-9.

Lock, A. L., B. M. Teles, J. W. Perfield, D. E. Bauman, and L. A. Sinclair. 2006. A conjugated linoleic acid supplement containing trans-10, cis-12 reduces milk fat synthesis in lactating sheep. J. Dairy Sci. 89:1525-1532.

Mark, E. C., and M. Pariza. 1998. The role of conjugated linoleic acid (CLA) in health. Int. Dairy J. 8:459-462.

Olson, D. W., D. L. Van Hekken, M. H. Tunick, K. A. Soryal, and S. S. Zeng. 2007. Effects of aging on functional properties of caprine milk made into Cheddar- and Colby-like cheeses. Small Rumin. Res. 70:218-227.

Perfield, J. W., II, G. Bernal-Santos, T. R. Overton, and D. E. Bauman 2002. Effects of dietary supplementation of rumen-protected conjugated linoleic acid (CLA) in dairy cows during established lactation. J. Dairy Sci. 85:2609-2617.

Rosenthal, A. J. 1999. Sensory techniques to study food texture. Pages 54-60 in Food Texture: Measurement and Perception. Aspen Publishers Inc., Gaithersburg, MD.

SAS Institute. 2002. SAS User's Guide: Statistics. SAS Inst., Inc. Cary, NC

Shingfield, K. J., J. Rouel, and Y. Chilliard. 2009. Effect of calcium salts of a mixture of conjugated linoleic acids containing trans-10, cis-12 in the diet on milk fat synthesis in goats. Br. J. Nutr. 1001:1006-1019.

Sinclair, L. A., A. L. Lock, R. Early, and D. E. Bauman. 2007. Effects of trans-10, cis-12 conjugated linoleic acid on ovine milk fat synthesis and cheese properties. J. Dairy Sci. 90:3326-3335.

Tunick, M. H., and D. L. Van Hekken. 2002. Torsion gelometry of cheese. J. Dairy Sci. 85:2743-2749.

Zeng, S. S., K. Soryal, B. Fekadu, B. Bah, and T. Popham. 2007. Predictive formulae for goat cheese yield based on milk composition. Small Rumin. Res. 69:180-186. 